D)

他

( 55$)-55-$

て埋没材が膨張するととになり、その結果、窝洞は小 さくなる。

鋳造りングによる抑制を緩和するためにはアスベス 卜裏装が必要であるが、窝洞の拡大は、アスベストの 枚数、その前処理条件によつて左右される。

貿 疑 (保存) 佐伯

リング内硬化膨張を抑制しないアスベストの厚さは 何 $\mathrm{mm}$ ですか。

応 答 若松良德

リングの内径、窩洞径アスベスト枚数の交互作用を 考虑しなければならないからら、単純な計測值を明言す るととはできえないが少くとも本実験の範囲内では 3 枚 $(0.4 \mathrm{~mm} \times 3)$ で最高值が併られた。な打実際の鋳 造で注、熱膨張と硬化膨張との関係も考虑しなければ ならないから、計測法を検討した上、十分な考察を行 いたいと考えている。

37. 低温鋳造および高温鏻造による各種合金の実験 成績について

中 止

38. 小児のメタルインレーについて (保存) 浦上景彦

小归用メタルインレーの研究の一端を担う意味で、 つぎの各種インレー用合金の鋳造収縮について実験を 行なつた。

試験材料蚛、1) Mirosilber、2) Miro 3、3) steybright、4) Progold、5) 夕銀打よび 7）至而K16合金の 7 種の合金である。

以下上記の番号は合金の種類を示す。鋳造の膨縮測 定用原型は MOD 形原型を使用し、その端面空淂 (h) は蠟型の空隙を鋳造金属による空陣から減した数值を 云う。蠟型製法には Shofu's gree inlay-wax を原 型に加温法接し、wax 凝固後は 安全剃为で削除し、 原型と枠とを同一平面になるようにサンドペーパーで 使上げた。つぎに直㺯 $1.63 \mathrm{~mm}$ のスプルー線を原型 に立て、原型汃ら引き出し、再復元し、その蠟型と原 型間の空障を予め移動測微計を用いて測定した。

\section{成 積}

G-C's New hygro investment (注水量O.C.C.) の場合：（）は例数、（）は最大、最小值を示す。 1) 191 (2) $(152 \sim 256) 、 2) 94(2)(8 \sim 152) 、 3) 90$ (2) $(16 \sim 224) 、 4) 160$ (3) $(8 \sim 216)$ 、 5) 108(2) (52 〜172）、6）190(2)（88〜256）打よび 7) 57(2)（16〜
124)

注水量 0.3C.C. 啺合：2） 138(2)（96～192）、5） 82(2)（32〜160）打よび 7) 40(2) (8〜88)

注水量 0.5C.C. の場合：2）157(2)（96〜212）、5） 144(2)88〜216）打よび 7) 63(2)（32〜88）

G-C's model investment $の$ 場合 : 2) 113(2) (44 〜 144)，5） 120(2)（32〜216）打よび 7) 86(2)（40〜 160) であつた。

考 察

以上の成績から鋳造収縮量の最も少ない金属は. 0.3 注水量の 7) で、つぎは０ C.C. 注水量の 7)、0.5 C.C. 注水量の 7)、0.3 C.C. 注水量の 5)、G C's model investment 使用の 7)、0 C.C. 注水量の 3)、0 C.C. 注水量の 2)、0 C.C. 注水量 $D 5$ ）、GC's model investment 使用の 2)、G-C's model investment $\odot$ 5)、0.3 C.C. 注水量の 2)、0.5 注 水量の 5)、0.5 C.C. 注水量の 2)、0 C.C. 注水量の 4）の順序で大となつている。乙れらの成績から合金 2)、3）打よび 5）の鋳造収縮量怯最近の雨科用鋳造 合金の標準的収縮として、さらに今後とも改良を加え たい。

\section{9. 合着用セメントが陶材の色調に及ぼす影響につ} いて

（保存）福岡隆俊、長野三代太、松尾 繁

ポーンレンジャケツトクラウンやポーセレンイン レーは種々なる長所を有し、最す理想的な修復物であ るといわれているが、その最大の長所は周囲の歯牙及 び米列の状驡に最も適合調和し、自然に見える色沢と 形態を与えることができる点にある。とのように審美 的に優れたジャケットクラウンやィンレーを口腔内の 支台菌あるいは简洞に合着する場合合着用セメントの 色の選択を誤れば時にポーセレンジケットクラウン やポーセレンインレーの色を損するととがある。われ われはこの点に注目しポーセレンジャケツトクラウン やポーセレンインレーの合着時クラウンやインレーの セツトに用いられる合着用セメントが陶材の色調に及 ぼす影響について種々実験した結果を報告する。

研究方法としては、種々の厚みを有する缶村成形物 と数種の合着用セメントを組合せ、合着用セメントの 色が陶材成形物の色調に及ばす影響を肉眼的に観察 した。

濃色のセメントは陶材の色を損する恐れがあるので ポーセレンシャヶツトクラウンの合着にさいしては合 
着用セメントの選択を䛊まらいように充分注意しなけ ればならない。

\section{0. 画科外来麻酔について}

$$
\text { (1口外) 西正 勝 }
$$

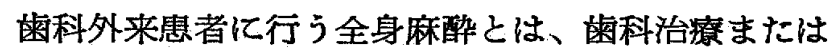
口腔外科手術後、比較的短時間で患者を帰宅させうる ことである。

贯科外来患者に対する麻醉の適応をみてみますと

1）強く恐怖心をいだく小児又は婦人の思者に対す る拔雪ならびに荬科治療

2）神径賀な患者やヒステリーな婦人

3）同麻に対する特異体質の患者

4）局麻方無効な場合

5）抜歯一般

使用例中男性 9 例、女性 4 例であつて、年令别にみ ますと、最小年令6才、最高46才までで、使用ガスの 種類は $\mathrm{G}-\mathrm{O}, \mathrm{G}-\mathrm{O}-\mathrm{F}$ ，で使用しました。導入時間 は平均 2 分で、手術時間は 3 分ないし 4 分までがはと んどであつた。覚醒時間は1分以内で覚醒していま す。13例中体動のあつたものは 4 例であつて、ラボ ナールを併用することによつて防ぐととが出来る嘔吐 が2例みられ、てれも絶食をさして扔けば防ぐてとが 出来る。夢は全例にみられ、種々の夢をみている。

麻醉実施にあつて、糜醉前の検查と思者の判定注重 要でありますので、前投薬、食事、排尿なとに関して 注意しなければなりません。

\section{追 加 西 正勝}

フローセンっペントレン全身麻醉は、口腔外科領城 の特殊性を满足させる数多くの利点がある。

一方口腔外科の手衡では、出血防止又は止血の目的 でアドレナリンを局所に使用するてとがきわめて多 い。しかしフローセン、ペントレン麻醉時にアドレナ リンを併用する可否については問題があり禁忌と考え ている人すあります。

アドレナリンが循環系に対してどの程度の影響を有 するか関して研究を行い現在の所断定とまではいえ ないがレプロキロ $5 \mathrm{r}$ まで使用のみと扎しを得てい ます。

\section{2. エポキシ樹脂を基材とした根管充境㓮の実験的 研究 (その3) \\ （治繁）吉田光雄、佐伯栄一。浅尾博己 村岡俊彦 \\ (口两）上野正康、北村勝也}

今回は、正常な結合組織に対する反応を検討するた めに、A H26の他に、吉田の処方せる吉田パスター、 N2、ホモスフラン、トリオシンクパスーを選んで、 比較実験を行なつた。実験動物には白ネズそを用い、 背部皮下結合組織内に一定量の薬㓮在埋入し、埋入後 1日、3日、7日、14日、21日、35日、56日のそれぞ れの時期に撗殺して、根管充填郕埋入部の組織を顕微 鏡的に検索した。な打、練和直後の根管充塓郕を埋入 した実験群と、練和した根管充填郕を $37^{\circ} \mathrm{C}$ の卯畉器

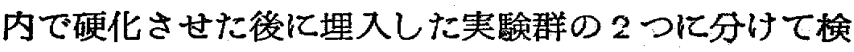
索を行なつた。

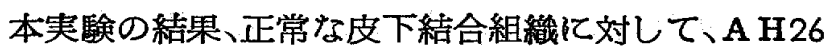
や吉田パスターが $\mathrm{N}_{2}$ やホモスフラン、トリオシンク パスターよりを刺激性が少なく、組織になじみ易いと いう事が観察された。しかしながら、N和やホモスフ ラン、トリオシンクパスターのように、刺激性が強く て、周囲組織えの反応性炎症が長く続いていてす、加 えつて、そのような性状が感染性の病的組織に対して より殺菌作用を高め、治海過程を促進するという事も 考えられるので、今後実験的に感染根管を作り、これ ら充填剤の歯周組織に対する影響について検索を行う つもりである。

\section{3. 根管清授剤に関する実験的研究（第 1 報）

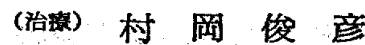

根管拡大を行なうに恰器機的拡大に化学的薬郕を併 用することはよりよい一風の根管搪大を扎ない根管 治療及び根管充填を容易にするのが目的である。それ で今回はこの種の化学的藥肪のうち、㙁酸を用い、を の象牙留に対する脱灰度について梌索した。すなわち 象牙賈を粉まにし、それに含有する Ca 量を $2 \% 、 4$ $\% 、 6 \% 、 8 \% 、 10 \%$ 塩酸の濃度別に 1 分、3 分、 5 分、10分、20分、30分と時間的に、Ca の溶出量を ポーラログラフを使用し湘定した。

その結果、 $4 \%$ と $8 \%$ 場合梳平均的に $\mathrm{Ca}$ の溶出 を晃たが、6\%及び10\%の濃度のは Ca の溶出率にか なりの変化が認められた。すなわち、合回は根管清授 用としての㙁酸の濃度は $4 \%$ \% 6\%ののがもつとも 